\title{
Limits on the Commission's Powers of Investigation
}

Two general rules limit or interrupt the Commission's powers of investigation: (1) general EU law principles and (2) the duty to respect the rights of the defence.

\subsection{General Principles of Limitation}

The powers of investigation of the European Commission have been increasing over the years. The European courts have developed or adapted general principles of European law to limit, frame or render more predictable the use of the Commission's powers. However, these principles appear to be moral statements and desiderates rather than rules that can tame the Commission's powers, and indeed the European courts have rarely relied on them to annul the Commission's decisions. Despite this, the importance of the general principles of limitation cannot be denied. First of all, they form the context in which the Commission operates and interacts with other EU institutions and with the undertakings. Second, they are common signposts that identify the not always obvious limits of power of the European Commission. Lastly and most importantly they are applicable to all EU competition law enforcement procedures in the EU. Even when due process is weak, as in the case of commitment procedures and settlements, the Commission is still bound by these general principles of EU law.

\subsubsection{The Principle of Proportionality}

The principle of proportionality is a general principle of EU law, expressly worded in Article 49(3) of the Charter which requires that the measures adopted by European Union institutions must not exceed what is appropriate and necessary for attaining the objective pursued. When there is a choice between several appropriate measures, the least onerous must be chosen. The disadvantages caused must not be disproportionate to the aims pursued. ${ }^{1}$

1 Alrosav Commission, quoted above, paragraph 98. 
Applying the principle of proportionality, the ECJ stated in Dow Chemicals Iberica and Others that every investigation by the Commission must be "necessary".

The Court noted that

in all the legal systems of the Member States, any intervention by the public authorities in the sphere of private activities of any person, whether natural or legal, must have a legal basis and be justified on the grounds laid down by law, and, consequently, those systems provide, although in different forms, protection against arbitrary or disproportionate intervention. The need for such protection must be recognized as a general principle of Community law. In that regard, it should be pointed out that the Court has held that it has the power to determine whether measures of investigation taken by the Commission under the ECSC Treaty are excessive. $^{2}$

The Court later explained that both the investigation as such and the Commission's specific discovery principles can be assessed against the proportionality principle, in order to ensure that they "do not constitute, in relation to the aim pursued by the investigation in question, a disproportionate and intolerable interference". ${ }^{3}$

\subsubsection{The Principle of Territoriality}

The European Commission is competent to investigate breaches of competition law that have occurred within the territory of the EU. However, due to the way in which businesses are currently located and working, this issue is far from being settled. In particular, the question arose as to whether the Commission can request information and documents from a company that is situated outside the territory of the EU. The Commission explained it has

only limited powers to obtain information from firms situated outside the EU. Under international law, the Commission is not empowered to conduct investigations outside the bounds of its territorial competence if they would infringe upon the national sovereignty of the non-member country in whose territory it was purporting to act. In such cases, the

2 C-97/87, Dow Chemical Ibérica and Others v Commission, ECLI:EU:C:1989:38o, paragraph 16.

3 C-94/oo, Roquette Frères $v$ Directeur général de la concurrence, de la consommation et de la répression des fraudes, and Commission of the European Communities, ECLI:EU:C:2002:603, paragraph 76 . 
Community can send out requests for information, but it cannot impose sanctions if a firm fails to comply. One option open to the Commission is to direct a request for information to a subsidiary of a non-EU firm which is based in the EU. ${ }^{4}$

\subsubsection{The Duty to Act within a Reasonable Time}

The Commission's investigations cannot last indefinitely; a decision must be reached within a reasonable time. The European Court of Justice has recognised the duty to act within a reasonable time as a general principle of community law and a corollary of the principle of sound administration. ${ }^{5}$

This principle is also now expressly mentioned in the Charter of Fundamental Rights which states in its Article 41(1) that "every person has the right to have his or her affairs handled within a reasonable time by the institutions, bodies, offices and agencies of the Union". The Charter does not distinguish between a general duty of the European institutions to act within reasonable deadlines and a special, more severe duty of the European Commission when it investigates market breaches under Articles 101 and 102 TFEU. Neither do the Charter, the Treaty or the European courts impose any deadlines on the Commission for investigating or closing cases. The European courts, however, will perform a case-by-case analysis in light of certain criteria such as the context of the case and its complexity, the conduct of the parties and of the Commission, and the interest of the undertakings concerned.

\subsubsection{Duty to State Reasons}

The duty to state reasons is an important principle of EU law that is now enshrined in Article 296 TFEU and Article 41(2) of the Charter of Fundamental Rights, which provides for the obligation of the administration to give reasons for its decisions.

In investigations covering Articles 101 and 102 TFEU, the Commission has a duty to give reasons both for its findings and for the penalties imposed. The European Court of Justice held, in a case concerning state aid, that the Commission is required to deliver its reasons in a clear and unequivocal fashion so as to

enable the persons concerned to ascertain the reasons for the measure and to enable the competent court to exercise its power of review. The

4 European Commission. Dealing with the Commission Notifications: complaints, inspections and fact-finding powers under Articles 85 and 86 of the EEC Treaty, quoted above, p. 22.

5 T-213/oo, CMA CGM and Others $v$ Commission, ECLI:EU:T:2003:76, paragraph 317. 
requirement to state reasons must be appraised by reference to the circumstances of each case. The question whether the statement of reasons meets the requirement of Article $253 \mathrm{EC}$ must be assessed with regard not only to its wording but also to its context and to all the legal rules governing the matter in question. ${ }^{6}$

\subsection{The Rights of the Defence}

\subsubsection{The Right to Be Heard}

The notification of the statement of objections to the undertakings concerned triggers the right to be heard, which is one of the pillars of the rights of the defence in European competition law. The right to be heard in European competition law has two aspects that complement each other: (a) the written comments and $(b)$ the oral hearing.

Regulation 1/2003 ensures that before taking decisions as provided for in Articles 7, 8, 23 and 24(2), the Commission must give the undertakings or associations of undertakings which are the subject of the proceedings the opportunity to be heard on the matters to which the Commission has taken objection. This is of crucial importance as the Commission can base its decisions only on objections on which the parties concerned have been able to comment. ${ }^{7}$

The right to be heard is not guaranteed by Regulation 1/2003 in commitment proceedings. In settlement proceedings, the right to be heard is guaranteed by Regulation 622/2008.

The parties concerned must be informed about all the objections raised against them in the statement of objections that must be sent to each party. The Commission must also set a time limit within which they can react to these objections. The concerned parties should prepare and send their reply, which can describe the facts that support or go against the Commission's assertions. They can also attach evidence in support of their allegations. Finally,

6 T-95/o3, Asociación de Empresarios de Estaciones de Servicio de la Comunidad Autónoma de Madrid and Federación Catalana de Estaciones de Servicio v Commission of the European Communities, ECLI:EU:T:2006:385, paragraph 108.

7 Council Regulation (EC) No 1/2003 of 16 December 2002 on the implementation of the rules on competition laid down in Articles 81 and 82 of the Treaty, quoted above, article 27 .

Commission Regulation (EC) No 773/2004 of 7 April 2004 relating to the conduct of proceedings by the Commission pursuant to Articles 81 and 82 of the EC Treaty Implementing Regulation, quoted above, article 11. 
they can propose that the Commission hears persons who may corroborate the facts set out in their submission. ${ }^{8}$

Aside from the parties concerned, the Commission can also hear in writing the complainants and other third parties. Complainants should be associated closely with the proceedings. ${ }^{9}$ When the Commission has issued a statement of objections relating to a matter in respect of which it has received a complaint, it must provide the complainant with a copy of the non-confidential version of the statement of objections and set a time limit within which the complainant may make known its views in writing. ${ }^{10}$

The Commission may also decide to hear third parties that have either been identified by the parties concerned or by the member states, or are deemed by the Commission to have an interest in the proceedings. Third parties may themselves request to be heard when they have an interest in the proceedings. Such applications to be heard shall, where they show a sufficient interest, be granted.11

As to the right to be heard orally, the interested parties can request an oral hearing before or, at the latest, when submitting their reply to the statement of objections. ${ }^{12}$

The Commission sets up the date of the oral hearing and invites the parties concerned or other interested third parties that the Commission will admit to the hearing. The Commission also invites the competition authorities of the member states to take part in the oral hearing. It may likewise invite officials and civil servants of other authorities of the member states. ${ }^{13}$

8 Commission Regulation (EC) No 773/2004 of 7 April 2004 relating to the conduct of proceedings by the Commission pursuant to Articles 81 and 82 of the EC Treaty Implementing Regulation, quoted above, article 10.

9 Council Regulation (EC) No $1 / 2003$ of 16 December 2002 on the implementation of the rules on competition laid down in Articles 81 and 82 of the Treaty, quoted above, article 27 .

10 Commission Regulation (EC) No 773/2004 of 7 April 2004 relating to the conduct of proceedings by the Commission pursuant to Articles 81 and 82 of the EC Treaty Implementing Regulation, quoted above, article 6(1).

11 Council Regulation (EC) No $1 / 2003$ of 16 December 2002 on the implementation of the rules on competition laid down in Articles 81 and 82 of the Treaty, quoted above, article $27(3)$.

12 Commission Regulation (EC) No 773/2004 of 7 April 2004 relating to the conduct of proceedings by the Commission pursuant to Articles 81 and 82 of the EC Treaty Implementing Regulation, quoted above, article 12.

13 Commission Regulation (EC) No 773/2004 of 7 April 2004 relating to the conduct of proceedings by the Commission pursuant to Articles 81 and 82 of the EC Treaty Implementing Regulation, quoted above, article 14(2) and (3). 
The hearing officer organizes and conducts the hearing. He fixes the date, the duration and the place of the hearing. He ensures that the oral hearing provides addressees of the statement of objections, other involved parties, as well as complainants and interested third persons which have been admitted to the oral hearing, with sufficient opportunity to express and develop their views. ${ }^{14}$ In order to ensure the proper preparation of the oral hearing, the hearing officer can, after consulting the director responsible, supply in advance to the persons invited to the hearing a list of questions which might be raised during the hearings. He can also indicate to the persons invited to the hearing the focal areas for debate, having regard, in particular, to the facts and issues that the parties want to raise..$^{15}$ The hearing officer may also ask for the prior written notification of the essential contents of the intended statements of persons invited to the hearing. ${ }^{16} \mathrm{He}$ has the competence to decide whether new documents should be admitted during the hearing and which persons should be heard on behalf of a party. ${ }^{17}$

After the hearing, the hearing officer submits an interim report and later a final report to the competent member of the Commission on the hearing and the conclusions he or she draws with regard to the respect for the effective exercise of procedural rights. ${ }^{18}$

The persons heard by the Commission may be assisted by their lawyers or other qualified persons..$^{19}$ Oral hearings are not public. ${ }^{20}$ Each person may be

14 Decision of the President of the European Commission of ${ }_{13}$ October 2011 on the function and terms of reference of the hearing officer in certain competition proceedings, oJ L 275, 20.10.2011, pp. 29-37, article 10.

15 Decision of the President of the European Commission of ${ }_{13}$ October 2011 on the function and terms of reference of the hearing officer in certain competition proceedings, quoted above, article $11(1)$.

16 Decision of the President of the European Commission of 13 October 2011 on the function and terms of reference of the hearing officer in certain competition proceedings, quoted above, article 11(3).

17 Decision of the President of the European Commission of ${ }_{13}$ October 2011 on the function and terms of reference of the hearing officer in certain competition proceedings, quoted above, article 12(2).

18 Decision of the President of the European Commission of ${ }_{13}$ October 2011 on the function and terms of reference of the hearing officer in certain competition proceedings, quoted above, articles 14 and 16 .

19 Commission Regulation (EC) No 773/2004 of 7 April 2004 relating to the conduct of proceedings by the Commission pursuant to Articles 81 and 82 of the EC Treaty Implementing Regulation, quoted above, article 14(4).

20 Commission Regulation (EC) No 773/2004 of 7 April 2004 relating to the conduct of proceedings by the Commission pursuant to Articles 81 and 82 of the EC Treaty Implementing Regulation, quoted above, article 14(6). 
heard separately or in the presence of other persons invited to attend, having regard to the legitimate interest of the undertakings in the protection of their business secrets and other confidential information.

With regard to the right to ask questions during the hearing, the hearing officer may grant the parties this right, however the existing legislation provides no guidance as to the circumstances in which this right may be granted. The statements made by each person heard have to be recorded, they can be disclosed upon request to the persons who attended the hearing. ${ }^{21}$

\subsubsection{Access to File}

Access to file is one of the most important procedural guarantees in European competition law proceedings and constitutes "a major breakthrough in the field of due process and an essential prerequisite for the exercise of the right to be heard". ${ }^{22}$ It is also an example of how fundamental rights have developed in the field of competition law through the common work of the European courts' case-law and the practice of the European Commission.

Access to file was initially construed to encompass only access to inculpatory evidence. However, from 1982 the Commission changed its practice, granting access to the entire file when investigating Articles 101 and 102. This practice was translated into a legal principle in 1991, when the CFI ruled that

in establishing a procedure for providing access to file in competition cases, the Commission imposed on itself rules exceeding the requirements laid down by the Court of Justice. (...) The Commission may not depart from rules which it has thus imposed on itself. (...) It follows that the Commission has an obligation to make available to the undertakings involved in Articles 81(1) proceedings all documents, whether in their favour or otherwise, which it has obtained during the course of the investigation, save where the business secrets of other undertakings, the internal documents of the Commission and other confidential information are involved. ${ }^{23}$

In ICI, the CFI relied on the equality of arms principle to explain that "in a competition case the knowledge which the undertaking concerned has of the file

21 Commission Regulation (EC) No 773/2004 of 7 April 2004 relating to the conduct of proceedings by the Commission pursuant to Articles 81 and 82 of the EC Treaty Implementing Regulation, quoted above, article 14(8).

22 Van Bael, op. cit., p. 176.

23 T-7/89, Hercules Chemicals v Commission, ECLI:EU:T:1991:75, paragraphs 53-54. 
used in the proceedings is the same as that of the Commission". ${ }^{24}$ In Solvay, the CFI held that the Commission should give the defendants access to the entire file: "it cannot be for the Commission alone to decide which documents are of use for the defence. The Commission must give the advisers of the undertaking concerned the opportunity to examine documents which may be relevant so that their probative value for the defence can be assessed". 25

In 1997, the Commission published guidelines on the right of access to file, aiming to bring its practice in line with the jurisprudence of the CJEU. In 200,5 the Commission issued a Notice on Access to File, replacing the guidelines adopted in 1997. In addition, Regulation on Procedure, the Implementing Regulation and the Charter provide for the right to have access to the Commission's file. However, access to the Commission's files under Articles 101 and 102 TFEU can only be granted to the addressees of the statement of objections.

The Commission's file consists of all documents which have been obtained, produced and/or assembled by DG COMP during the investigation. Documents collected during an investigation which, following a more detailed examination, prove to be unrelated to the subject matter of the case in question, may be returned to the undertaking from which they have been obtained. Upon return, these documents will no longer constitute part of the file. ${ }^{26}$

Accessible documents are all documents that compose the Commission's file, with the exception of internal documents, business secrets of other undertakings, or other confidential information. ${ }^{27}$

Access to file is granted upon request and, normally, on a single occasion, following the communication of the statement of objections to the parties concerned. As a general rule, therefore, no access can be granted to other parties' replies to the Commission's objections unless such documents constitute new evidence - whether of an incriminating or of an exculpatory nature - and the Commission intends to rely on it. ${ }^{28}$

\footnotetext{
24 T-37/91, ICI v Commission, ECLI:EU:T:1995:119, paragraph 64.

25 T-3o/91, Solvayv Commission, ECLI:EU:T:1995:115, paragraph 81.

26 Commission Notice on the rules for access to the Commission file in cases pursuant to Articles 81 and 82 of the EC Treaty, Articles 53, 54 and 57 of the EEA Agreement and Council Regulation (EC) No 139/2004, OJ C 325, 22.12.2005, pp. 7-15, p. 8.

27 Commission Notice on the rules for access to the Commission file in cases pursuant to Articles 81 and 82 of the EC Treaty, Articles 53, 54 and 57 of the EEA Agreement and Council Regulation (EC) No 139/2004, quoted above, p. 8.

28 Commission Notice on the rules for access to the Commission file in cases pursuant to Articles 81 and 82 of the EC Treaty, Articles 53, 54 and 57 of the EEA Agreement and Council Regulation (EC) No 139/2004, quoted above, p. 12.
} 
Access to file may be granted in one of the following ways, taking due account of the technical capabilities of the parties:

- by means of CD-ROM(s) or any other electronic data storage device as may become available in future;

- through copies of the accessible file in paper form sent to them by mail; or

- by inviting them to examine the accessible file on the Commission's premises.

The Commission may choose any combination of these methods. In order to facilitate access to the file, the parties receive an enumerative list of documents setting out the content of the Commission file. ${ }^{29}$

The Notice on Access to File describes two main types of non-accessible documents: the Commission's internal documents and documents containing business secrets and other confidential information.

Article 15(2) stipulates that the right of access to the file does not extend to internal documents of the Commission or of the competition authorities of the member states. The right of access to the file does not cover the correspondence between the Commission and the competition authorities of the member states or between the latter where such correspondence is contained in the file of the Commission.

The Commission's internal documents can be neither incriminating nor exculpatory and they do not constitute, therefore, part of the evidence on which the Commission can rely in its assessment of a case. Thus, the parties will not be granted access to internal documents in the Commission file.

An important part of the Commission's internal documents are the minutes of meetings. There is however no obligation for the Commission to draft any minutes of meetings with any person or undertaking. More importantly, if the Commission chooses to make notes of such meetings, such documents constitute the Commission's own interpretation of what was said at the meetings, for which reason they are classified as internal documents. In exceptional cases, however, the Commission can disclose the content of its minutes. Thus, for example, where the undertaking has agreed, the minutes will be made accessible after deletion of any business secrets or other confidential information. Such agreed minutes constitute part of the evidence on which the Commission can rely in its assessment of a case. ${ }^{30}$

29 Commission Notice on the rules for access to the Commission file in cases pursuant to Articles 81 and 82 of the EC Treaty, Articles 53, 54 and 57 of the EEA Agreement and Council Regulation (EC) No 139/2004, quoted above, p. 15 .

30 Commission Notice on the rules for access to the Commission file in cases pursuant to Articles 81 and 82 of the EC Treaty, Articles 53, 54 and 57 of the EEA Agreement and Council Regulation (EC) No 139/2004, quoted above, p. 9. 
Article 15(2) of the Implementing Regulation provides that business secrets and other confidential information are not required to be disclosed under the right of access to file.

Business secrets are defined broadly as including technical and/or financial information relating to an undertaking's know-how, methods of assessing costs, production secrets and processes, supply sources, quantities produced and sold, market shares, customer and distributor lists, marketing plans, cost and price structures and sales strategies. ${ }^{31}$

Other confidential information may include "information other than business secrets, which may be considered as confidential, insofar as its disclosure would significantly harm a person or undertaking". ${ }^{32}$ Confidential information is case-specific and it may include, for example, information provided by third parties about undertakings which are able to place very considerable economic or commercial pressure on their competitors or on their trading partners, customers or suppliers, including retaliatory measures. The notion of other confidential information may include, therefore, information that would enable the parties to identify complainants or other third parties where those have a justified wish to remain anonymous. ${ }^{33}$

The Commission can either accept the confidentiality claims when they are justified or reject them, in which case, if the party insists on confidentiality, it will be for the hearing officer to settle the matter.

The Commission explains that the confidential nature of a document is not a bar to its disclosure if such information is an inculpatory or an exculpatory document. In this case, the need to safeguard the rights of the defence of the parties through the provision of the widest possible access to the Commission file may outweigh the concern to protect confidential information of other parties. It is for the Commission to assess whether those circumstances apply to any specific situation. This calls for an assessment of all relevant elements, including the relevance of the information in determining whether or not an infringement has been committed, and its probative value; whether the

31 Commission Notice on the rules for access to the Commission file in cases pursuant to Articles 81 and 82 of the EC Treaty, Articles 53, 54 and 57 of the EEA Agreement and Council Regulation (EC) No 139/2004, quoted above, p. 10.

32 Commission Notice on the rules for access to the Commission file in cases pursuant to Articles 81 and 82 of the EC Treaty, Articles 53, 54 and 57 of the EEA Agreement and Council Regulation (EC) No 139/2004, quoted above, p. 10.

33 Commission Notice on the rules for access to the Commission file in cases pursuant to Articles 81 and 82 of the EC Treaty, Articles 53, 54 and 57 of the EEA Agreement and Council Regulation (EC) No 139/2004, quoted above, p. 10. 
information is indispensable; the degree of sensitivity involved; and the preliminary view of the seriousness of the alleged infringement. ${ }^{34}$

\subsubsection{The Right to Remain Silent}

The right to remain silent is a principle which argues that no one can be compelled to incriminate oneself. This principle prevents extortion of information or the use of investigative measures that force the accused person to acknowledge his guilt.

There is no express provision concerning the right to remain silent in European competition law. On the contrary, the legislation places an obligation of cooperation on the undertakings, an obligation that encompasses the duty to answer requests for information, the duty to provide requested documents and the duty to collaborate during inspections.

However, in Orkem, the Court of Justice developed an exception to the undertakings' obligation of cooperation with the Commission. The Court argued that an undertaking has the right to remain silent when faced with questions that can be viewed as possibly requiring the company to admit the existence of an infringement. ${ }^{35}$

The EU Courts held in a later case that "a right to silence can be recognized only to the extent that the undertaking concerned would be compelled to provide answers which might involve an admission on its part of the existence of an infringement". ${ }^{36}$ The CFI explained that this approach was motivated by the need to preserve the efficiency of the Commission's enforcement powers. ${ }^{37}$

This exception is now codified in Recital 23 of the preamble to the Regulation 1/2003 which highlights that "when complying with a decision of the Commission, undertakings cannot be forced to admit that they have committed an infringement, but they are in any event obliged to answer factual questions and to provide documents, even if this information may be used to establish against them or another undertaking the existence of an infringement".

Thus, undertakings must produce all the documents that the Commission requests, but should answer only those questions which are not directly incriminatory. The Commission itself explained that

34 Commission Notice on the rules for access to the Commission file in cases pursuant to Articles 81 and 82 of the EC Treaty, Articles 53, 54 and 57 of the EEA Agreement and Council Regulation (EC) No 139/2004, quoted above, p. 11.

35 C-374/87, Orkem v Commission, ECLI:Eu:C:1989:387, paragraph 35.

36 T-236/o1, Tokai Carbon v Commission, ECLI:EU:T:2004:118, paragraph 402.

37 T-236/o1, Tokai Carbon v Commission, quoted above, paragraph 402-403. 
it is not permitted to ask leading questions, where giving a truthful answer would lead the firm to confess to an infringement. (...) It remains the task of the Commission to prove the facts, as it has found them, in support of the conclusion that there has been an infringement of the competition rules. Requiring firms to answer oppressive questions would effectively deprive them of their right to a hearing in the subsequent adjudicatory stage of proceedings. ${ }^{38}$

38 European Commission. Dealing with the Commission Notifications: complaints, inspections and fact-finding powers under Articles 85 and 86 of the EEC Treaty, quoted above. 